\title{
AMMI stability for starch yield of cassava in the acid area for determining clones' stability
}

\author{
Sholihin ${ }^{*}$ \\ Indonesian Legumes and Tuber Crops Research Institute (ILETRI), Jl. Raya Kendalpayak Km 8, PO. \\ Box 66, Malang, East Java, Indonesia
}

\begin{abstract}
The study aimed to evaluate the phenotypic stability of cassava promising clones' cassava clones in acidic regions based on AMMI stability. The study was done during 2015-2018 in several environments in Lampung. The study was done using a randomized complete block design with three replications. Plants were planted in $5 \mathrm{~m} \mathrm{x} 4.8 \mathrm{~m}$ plot size, with $1 \mathrm{~m}$ distance between rows and $0.8 \mathrm{~m}$ within row. The plants were fertilized with $93 \mathrm{~kg}$ $\mathrm{N}, 36 \mathrm{~kg}$ P2O5 and $60 \mathrm{~kg} \mathrm{~K} 2 \mathrm{O}$ per hectare. Seven cassava promising clones and two check varieties were used in this study. Data were analyzed using Excel, MSTAT-C and PBTOOLs. Research showed that compared with clone PC2, PC3, PC5 and clone PC7, clone PC1, PC4, PC6, UJ3 and clone UJ5 are more stable. According to the AMMI analysis, based on the sevenmonth starch yield, the important environmental factors that determined the stability of cassava clones are the content of $\mathrm{N}$ and P2O5 in the upper soil layer and the cation exchange capacity ground. The starch yield in seven months of PC4 was the highest among the clones. Clone PC4 is potential to be developed in acid area.
\end{abstract}

\section{Introduction}

Cassava starch is one of industry product using cassava as raw material. Thailand is the biggest exporting country for cassava starch, followed by Vietnam. Indonesia exported the cassava starch only $0.2 \%$. Most cassava starch from Thailand and Vietnam exported to China. The biggest importing country for cassava starch was China and Indonesia [1]. Export price for cassava starch in Bangkok affected the price of starch in the regional including Indonesia. Export price for cassava starch in Bangkok range 425-475 US\$/ton in 2020. The highest price of cassava starch during 2020 was in December 2020 (US\$ 475/ton). The lowest price of cassava starch during 2020 was in April (US\$ 425/ton). This pattern was different from the pattern in 2019 in which the highest price of cassava starch was in April (US\$ 469/ton), and the lowest price was in July (US\$ 425/ton). The price of cassava starch was affected mostly by balance of supply-demand of cassava starch. During 2016-2020, the high price of cassava starch in Bangkok was in 2018, at that time, the price of the fresh tuber in Indonesia was Rp. $1700 / \mathrm{kg}$ in some factory starch. The low price of cassava starch in Bangkok during 2016-2020 was in 2017, at that time, the price of the fresh tuber in Indonesia was lower than Rp.1000, - in factory starch. The price of cassava starch in 2020 was lower

* Corresponding author: sholhalim@,gmail.com 
than that in 2019 [2]. In 2018, the global tapioca starch market was worth 40.53 billion U.S. dollars and is expected to reach 66.84 billion U.S. dollars by 2026, with a CAGR (compound annual growth rate) of $6.50 \%$ during the forecast period.[3].

Tuber yield is important character for farmer as a basis in choosing the variety. So the tuber yield of new variety should be higher than the existing variety or similar to them. Diameter of tuber, number of tuber/plant and harvest index determine the tuber yield $[4,5]$. Another factor that important for farmer as basis in selecting the variety for their land is starch content. Price of cassava with high starch content higher than that of low starch content. $\mathrm{HCN}$ content of tuber also is important character for farmer in choosing the variety used. Basically, there are two groups of cassava based on HCN content, not bitter cassava (HCN content $<50 \mathrm{ppm}$ ) and bitter cassava ( $\mathrm{HCN}$ content $\geq 50 \mathrm{ppm}$ ). For starch factory, both cassava can be used as raw materials. The advantage of using a bitter cassava for cassava plantation is safe from theft. The advantage of using a not bitter cassava is the product can be used either for row material of starch factory and for table foods.

In general, cassava planted in different kind of soil types, one of them is in Ultisol soil. About $22 \%$ of cassava plant in Indonesia were planted in ultisol [6]. Lampung is the center of cassava productions in Indonesia. The soil type in Lampung is Ultisol, and the soil $\mathrm{pH}$ ranges from 3.9 to 4.7 [7]. This environment needs cassava varieties which are tolerant to acid soil. Tuber yield, starch content, and starch yield of cassava clones are the result of interaction between clones and environment. There are two type of environment, predictable and unpredictable. When developing new varieties, promising clones must be tested in certain environments and seasons or years to test their stability and adaptability.

There are some methods to analyses the data for the experiments conducted in some environments, seasons or years. One of them is AMMI method. AMMI is main effects additives and multiplicative interactions. The stability of the genotype can be determined using the AMMI map. Genotype that is near the central point $(0.0)$ is more stable than the genotype that is far from central point (0.0). Environment factors affecting the stability of genotype can be determined by calculation the correlation coefficient between data environments and environment IPCA (Interaction Principal Component Analysis) values. Many scientists use AMMI model for interpreting the experiment conducted in some environments and seasons or years $[8,9,10,11,12]$. Promising clones identified in previous cassava breeding activities need to be tested in different locations/environments. The study aimed to evaluate the phenotypic stability of cassava promising clones' cassava clones in acidic regions based on AMMI stability.

\section{Materials and methods}

The study was done during 2015-2018 with same treatments (Clone PC1, PC2, PC3, PC4, PC5, PC6, PC7, two check varieties, UJ3 and UJ5) in some environments in Lampung. All experiments during 2015-1018 were done using a randomized complete block design with three replications. Plants were planted in $5 \mathrm{~m} \mathrm{x} 4.8 \mathrm{~m}$ plot size with $1 \mathrm{~m}$ distance between rows and $0.8 \mathrm{~m}$ within row. Clones were planted in a $5 \mathrm{~m} \mathrm{x} 4.8 \mathrm{~m}$ plot with a plant spacing of $1 \mathrm{~m} \mathrm{x} 0.8 \mathrm{~m}$. Plants were fertilized with $93 \mathrm{~kg} \mathrm{~N}, 36 \mathrm{~kg} \mathrm{P}_{2} \mathrm{O}_{5}$, and $60 \mathrm{~kg} \mathrm{~K}_{2} \mathrm{O}$ per hectare. Characteristics of environments were as follows: range of $\mathrm{N}$ content $0.06 \%-0.13 \%, \mathrm{P}_{2} \mathrm{O}_{5}$ content 1.36 ppm-29.9 ppm, K content (0.05-0.25) me/100 g, pH of soil 3.9-5.1, CEC (96.8223.9) me/100 g, Al-dd (0.00-0.88) $\mathrm{Cmol}+/ \mathrm{kg}$, and C-organic matter (0.46-1.12) \%. Number of rainy days/months of trial locations was 7-25 days and a total rainfall/month of trial locations was 31-633 mm. The altitude of the trial locations was $44-135 \mathrm{~m}$ above sea level. The software Excel, MSTAT-C and PBTOOLs were used to analyze the data. The AMMI Stability Value (ASV) was calculated using the following formula: 


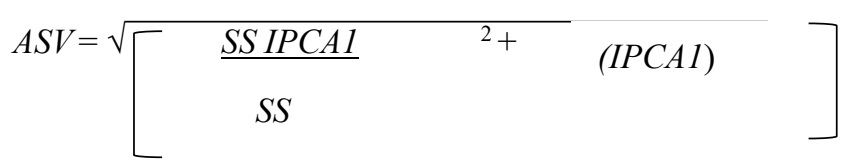

$(I P C A 2)^{2}$

(1)

\section{Result and discussion}

In each environment, clone factor was important for starch production after seven months (Table 1). In 2015, in Lampung Selatan, the starch yields of the test clones ranged from 6,533-10.06 tons/ha, with an average of 8,516 tons/ha. The highest starch yield was clone PC4. The starch yield of clones PC2, PC5, PC6, PC7 and UJ5 was similar to that of clone PC4. The range of starch yield of tested clones in Lampung Timur 2015 was 4.053-8.710 $\mathrm{t} /$ ha with average $6.715 \mathrm{t} / \mathrm{ha}$. Clone PC4 is also the tallest, significantly taller than UJ3 and UJ5 (control varieties). The results of experiments conducted at Lampung Selatan in 2016 showed that the starch yield of PC4 was also the highest, which was also significantly higher than that of the control variety. In Lampung Tengah, the clone PC4 is also the highest, significantly higher than UJ3. However, in Lampung Timur, PC5 produced the highest starch yield but clones PC4, PC6 and UJ3 was similar to that clone. During 2017, the starch yield of clone PC4 was the highest in Lampung Selatan, it was significantly higher than UJ3 and UJ5 (check varieties). In Lampung Timur, PC5 produced the highest starch yield but clone PC4, PC6 and UJ3 were similar to that clone.

During 2018, the experiment was done in 1 environment, that was Tulang Bawang Barat, and the result showed that clone PC4 produced the highest starch yield, and it was also significantly higher than UJ3. UJ3 and UJ5 were used as checks in this study because many farmer use these varieties. Krisdiana [13] reported that $68 \%$ of cassava farmers in Lampung planted UJ3 (Rayong 60) and 31\% planted UJ5 (Kasesart 50). From the average value of certain environments, clone PC4 had the highest starch yield in 7 months, which was significantly higher than UJ3 and UJ5 (Table 1). UJ3 and UJ5 produced starch $5.206 \mathrm{t} / \mathrm{ha}$ and $5.871 \mathrm{t} / \mathrm{ha}$, respectively. While clone PC4 produced starch $7.213 \mathrm{t} / \mathrm{ha}$. So, clone PC4 produced starch higher than that of UJ3. This increasing value of PC4 compare to UJ3 is equal to Rp 14,049,000, -. In 2015, harvesting area of cassava in Lampung was 277377 ha [14]. Krisdiana [13] reported that $68 \%$ of cassava farmers in Lampung planted UJ3 (Rayong 60.). It was estimated that harvesting area of UJ3 in Lampung in 2015 was 189976 ha. There is a potential increasing value about 2669 billion rupiah by replacing UJ3 with clone PC4 in Lampung. Therefore, this promising clone have a potency to be developed as raw material for cassava starch factory in the future to increase their competitiveness. 


\begin{tabular}{|c|c|c|c|c|c|c|c|c|c|c|c|c|c|}
\hline & & & 0 & $\infty$ & $\checkmark$ & $a$ & ur & $\Delta$ & $\omega$ & $N$ & - & z & \multirow{4}{*}{ 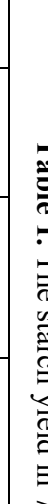 } \\
\hline$\stackrel{\Omega}{<}$ & $\begin{array}{l}5 \\
6 \\
0 \\
\text { un } \\
0^{\circ}\end{array}$ & 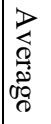 & $\begin{array}{l}\frac{\partial}{\partial} \\
\frac{\partial}{d} \\
\frac{\partial}{d}\end{array}$ & 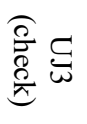 & $\widetilde{\Omega}$ & $\widetilde{\Omega}$ & $\vec{O}$ & $\bar{\AA}$ & $\widetilde{\omega}$ & $\widetilde{N}$ & $\widetilde{\Omega}$ & 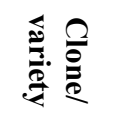 & \\
\hline$\nsubseteq$ & $\begin{array}{l}N \\
0 \\
\omega \\
\omega\end{array}$ & $\begin{array}{l}\infty \\
\dot{u} \\
a\end{array}$ & $\begin{array}{l}\infty \\
\dot{0} \\
\infty \\
0 \\
\tilde{\sigma}\end{array}$ & $\begin{array}{l}\dot{y} \\
\dot{\alpha} \\
o \\
\sigma\end{array}$ & $\begin{array}{l}\infty \\
\stackrel{N}{N} \\
\tilde{v}\end{array}$ & $\begin{array}{l}0 \\
\dot{\tilde{s}} \\
w \\
\tilde{\sigma}\end{array}$ & $\begin{array}{l}\infty \\
\dot{0} \\
w \\
w \\
\tilde{\sigma}\end{array}$ & 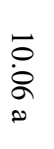 & $\begin{array}{l}\text { uे } \\
\dot{w} \\
0 \\
0\end{array}$ & 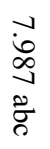 & $\begin{array}{l}0 \\
\text { in } \\
\omega \\
\infty\end{array}$ & 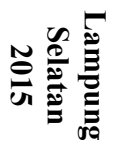 & \\
\hline$\Xi$ & $\begin{array}{l}\vec{\sigma} \\
\vec{b}\end{array}$ & $\begin{array}{l}\stackrel{\partial}{\vec{v}} \\
\vec{u}\end{array}$ & $\begin{array}{l}\stackrel{a}{\hat{N}} \\
\text { o }\end{array}$ & $\begin{array}{l}u \\
\dot{\omega} \\
\omega \\
\dot{z}\end{array}$ & $\begin{array}{l}\dot{0} \\
\dot{0} \\
\dot{\omega} \\
0\end{array}$ & $\begin{array}{l}\stackrel{v}{u} \\
\vec{w} \\
\tilde{\sigma}\end{array}$ & 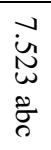 & $\begin{array}{l}\stackrel{\infty}{\ddot{\partial}} \\
0 \\
\infty\end{array}$ & 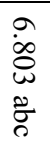 & $\begin{array}{l}u \\
\dot{\phi} \\
\dot{2} \\
\&\end{array}$ & $\begin{array}{l}\dot{v} \\
\text { aे } \\
\tilde{\sigma}\end{array}$ & 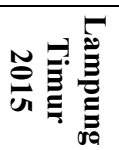 & \\
\hline$\vec{\forall}$ & $\overrightarrow{\dot{u n}}$ & $\begin{array}{l}0 \\
\dot{0}\end{array}$ & 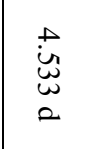 & $\begin{array}{l}u \\
\dot{a} \\
\dot{1} \\
\text { ह }\end{array}$ & $\begin{array}{l}\stackrel{p}{\dot{w}} \\
\tilde{\omega} \\
\underline{e}\end{array}$ & $\begin{array}{l}\dot{y} \\
\dot{+} \\
\dot{\omega} \\
\tilde{\sigma}\end{array}$ & $\begin{array}{l}+\infty \\
\infty \\
\pm \\
2\end{array}$ & $\underset{\infty}{\stackrel{\infty}{+}}$ & $\begin{array}{l}\ddot{1} \\
\dot{+} \\
\dot{\omega} \\
\check{2}\end{array}$ & $\begin{array}{l}\text { ù } \\
\text { w } \\
\text { vै }\end{array}$ & $\begin{array}{l}a \\
\infty \\
w \\
\tilde{c} \\
\sigma\end{array}$ & 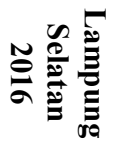 & 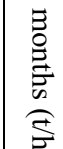 \\
\hline $\bar{i}$ & $\frac{\bar{n}}{n}$ & $\frac{u}{\dot{n}}$ & $\begin{array}{l}u \\
\dot{a} \\
0 \\
\dot{\sigma}\end{array}$ & $\begin{array}{l}u \\
0 \\
0 \\
0 \\
\tilde{\sigma}\end{array}$ & 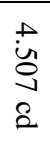 & $\begin{array}{l}\text { वे } \\
\text { స̃ } \\
0 \\
\tilde{\sigma}\end{array}$ & $\begin{array}{l}\hat{\delta} \\
8 \\
0\end{array}$ & $\begin{array}{l}\stackrel{0}{\hat{u}} \\
\tilde{\omega} \\
\tilde{\sigma}\end{array}$ & $\begin{array}{l}w \\
\infty \\
u \\
u \\
2\end{array}$ & $\begin{array}{l}u \\
\omega \\
\sigma \\
\sigma \\
\sigma\end{array}$ & $\begin{array}{l}u \\
u n \\
\dot{t} \\
g \\
\delta\end{array}$ & 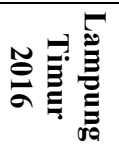 & 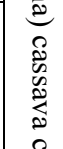 \\
\hline $\begin{array}{l}\bar{a} \\
\text { an }\end{array}$ & $\bar{\omega}$ & $\begin{array}{l}w \\
\infty \\
\infty\end{array}$ & $\begin{array}{l}\vec{w} \\
\dot{\infty} \\
w \\
\tilde{\sigma}\end{array}$ & $\begin{array}{l}N \\
\infty \\
w \\
\omega \\
0\end{array}$ & $\begin{array}{l}n \\
\dot{\rho} \\
\dot{\omega} \\
0\end{array}$ & $\begin{array}{l}\overrightarrow{0} \\
\dot{\omega} \\
\omega\end{array}$ & $\begin{array}{l}N \\
\dot{0} \\
0 \\
0 \\
0\end{array}$ & $\begin{array}{l}u \\
\dot{N} \\
\omega \\
\infty\end{array}$ & $\begin{array}{l}w \\
\dot{u} \\
\infty \\
\dot{\sigma} \\
\sigma\end{array}$ & $\begin{array}{l}w \\
\text { un } \\
\text { Ju } \\
\text { g }\end{array}$ & $\begin{array}{l}+ \\
\dot{\hat{N}} \\
\infty\end{array}$ & 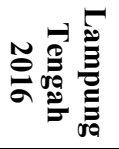 & 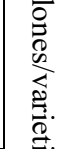 \\
\hline $\bar{u}$ & $\stackrel{\vec{N}}{\stackrel{\sim}{\sim}}$ & 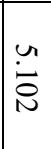 & $\begin{array}{l}u \\
\dot{\omega} \\
\dot{\sigma} \\
\sigma\end{array}$ & $\begin{array}{l}+ \\
\dot{i} \\
\dot{8} \\
0\end{array}$ & $\begin{array}{l}u \\
i \omega \\
\omega \\
\tilde{\omega} \\
\tilde{\sigma}\end{array}$ & $\begin{array}{l}a \\
\vdots \\
0 \\
\tilde{\sigma}\end{array}$ & $\begin{array}{l}+\overrightarrow{1} \\
\dot{+} \\
\dot{0} \\
0\end{array}$ & $\begin{array}{l}\text { ì } \\
\text { d } \\
\text { D }\end{array}$ & $\begin{array}{l}+\overrightarrow{+} \\
\dot{\leftrightarrow} \\
0 \\
0\end{array}$ & $\begin{array}{l}+\vec{a} \\
\vec{j} \\
0\end{array}$ & $\begin{array}{l}+ \\
\infty \\
\dot{0} \\
\circ \\
0\end{array}$ & 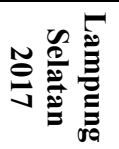 & $\begin{array}{l}\overrightarrow{0} \\
0 \\
0 \\
0 \\
9 \\
0 \\
0 \\
0 \\
0\end{array}$ \\
\hline$\vec{i}$ & $\stackrel{i}{\sim}$ & $\frac{1}{\dot{a}}$ & $\begin{array}{l}u \\
\dot{a} \\
0 \\
o \\
\sigma\end{array}$ & $\begin{array}{l}u n \\
\dot{0} \\
\dot{w} \\
\tilde{\sigma}\end{array}$ & 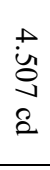 & 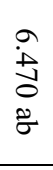 & $\begin{array}{l}\hat{b} \\
\text { ò } \\
0\end{array}$ & $\begin{array}{l}\stackrel{0}{\mathcal{u}} \\
\tilde{\omega} \\
\tilde{\sigma}\end{array}$ & $\begin{array}{l}w \\
\infty \\
w \\
y \\
e\end{array}$ & $\begin{array}{l}u \\
\dot{w} \\
o \\
o \\
\sigma\end{array}$ & $\begin{array}{l}u \\
u \\
u \\
o \\
o \\
o\end{array}$ & 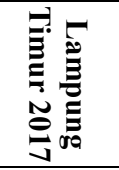 & 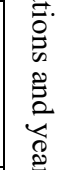 \\
\hline $\bar{u}$ & 㐫 & $\begin{array}{l}n \\
\dot{0} \\
\infty\end{array}$ & 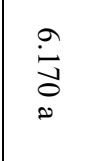 & $\begin{array}{l}w \\
\dot{0} \\
u \\
0 \\
0\end{array}$ & 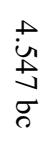 & 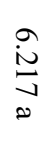 & $\begin{array}{l}\omega \\
\dot{N} \\
\text { J } \\
0\end{array}$ & $\begin{array}{l}\stackrel{\infty}{i} \\
\underset{\infty}{\infty} \\
\infty\end{array}$ & 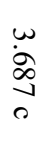 & 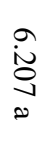 & $\begin{array}{l}\omega \\
\infty \\
\infty \\
\omega \\
\tilde{\sigma}\end{array}$ & 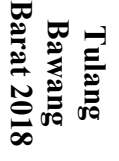 & $\begin{array}{l}\text { No } \\
\stackrel{0}{u} \\
\hat{1} \\
\text { N. } \\
\infty\end{array}$ \\
\hline $\overrightarrow{\tilde{N}}$ & 它 & $\begin{array}{l}u \\
\infty \\
w \\
\alpha\end{array}$ & 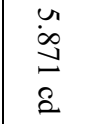 & $\begin{array}{l}u \\
\text { ĩ } \\
o \\
o \\
0\end{array}$ & $\begin{array}{l}\stackrel{+}{\vec{a}} \\
\stackrel{+}{+} \\
0\end{array}$ & 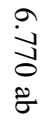 & $\begin{array}{l}u \\
\ddot{0} \\
\text { ठ } \\
2\end{array}$ & $\begin{array}{l}\stackrel{\sim}{N} \\
\underset{\omega}{\omega} \\
\infty\end{array}$ & 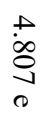 & $\begin{array}{l}\ddot{1} \\
\dot{\infty} \\
0 \\
2\end{array}$ & $\begin{array}{l}a \\
\dot{\omega} \\
\tilde{\sigma} \\
\dot{\sigma}\end{array}$ & $\begin{array}{l}3 \\
\text { 3. } \\
\stackrel{3}{=}\end{array}$ & \\
\hline
\end{tabular}




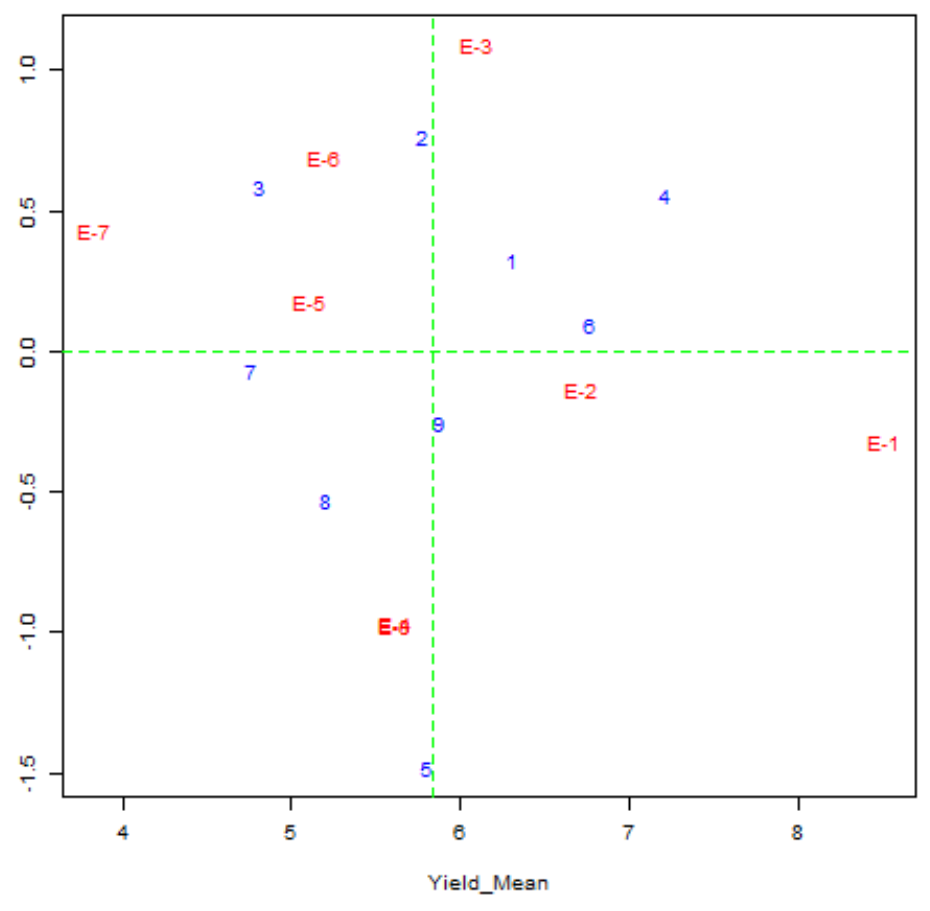

Fig. 1. IPCA1 map and starch production in seven months

Note 1: PC1; 2: PC2; 3: PC3; 4: PC4; 5: PC5; 6: PC6; 7: PC7; 8: UJ3; 9: UJ5

E-1 : Lampung Selatan 2015 E-2: Lampung Timur 2015

E-4 : LampungTimur2016 E-5: Lampung Tengah 2016

E-7 : Lampung Timur 2017 E-8: Tulang Bawang Barat 2018
E-3: Lampung Selatan 2016

E-6: Lampung Selatan 2017

Table 2 shows the result of variance analysis. The coefficient of variation $(\mathrm{CV})$ of the pooled analysis data was $15 \%$, indicating that the experimental precision was good. Clones significantly interacted with environments which is common for quantitative characters. It was reported the present of interaction genotype $\mathrm{x}$ environment for yield in cassava, chickpea, black gram, triticale and soybean [10, 15-18]. The analysis of variance of the AMMI model based on starch production is shown in Table 3. The effect of interaction of clones and environments was significant. The source of clone $\mathrm{x}$ environment interaction variation with AMMI model can be divided into some components, namely IPCA1 to IPCA6. IPCA1, IPCA2 and IPCA3 components were significant, while IPCA4, IPCA5 and IPCA6 were not significant IPCA 1 contributed $53 \%$ of the square sum interaction, IPCA 2 contributed $27 \%$, and IPCA3 contributed 16\%. Then, the cumulative contribution of ICPA 1, ICPA 2 and ICPA 3 was $86 \%$. So, there was $14 \%$ represents the noise, i.e., the random variation resulting from the influence of micro environmental factors with no agronomic importance. Morais et al. [10] reported in the experiments in 3 environments only IPCA1 that was significant with the contribution of $72.88 \%$. Sara et al. [19] reported that in 9 environments experiments they found four IPCA with accumulation contribution of $92.2 \%$.

The graph of IPCA1 and the average value of the starch yield are shown in Figure 1. Based on this graph, it can be determined that clones at a point on the horizontal axis indicate that these clones have the same main effect (starch yield), and clones at a point on the vertical axis indicate that these clones have the same interaction effect. Clone 2 (PC2) and clone 5 
(PC5) had similar starch yields, but the effects of positional interaction were different. Clone PC2 has a positive interaction with the E3 environment, while clone PC5 has a negative interaction with the $\mathrm{E} 3$ environment.

Figure 2 shows the IPCA1 and IPCA2 graph based on starch production. As can be seen from the figure, the environment used was suitable for analysis. The location of E1 (Lampung Selatan 2015) was far from E3 (Lampung Selatan 2016), E6 (Lampung Selatan 2017) and E8 (Tulang Bawang Barat 2018), which means that the environment used was diverse. E-8 (Tulang bawang Barat) environment is separated from the E-3 environment on IPCA1. N content and CEC of E-8 environment were lower than that in E-3 environment. $\mathrm{P}_{2} \mathrm{O}_{5}$ content of E-8 environment was higher than E-3 environment. Based on this graph, the stability of the clone can be determined. Clone 1 (PC1), 4 (PC4), 6 (PC6), 8 (UJ3) and Clone 9 (UJ5) compared to clone 2 (PC2), 3 (PC3), 5 (PC5) and Clone 7(PC7) were more stable. Sara et al. [19] pointed out that the AMMI model does not provide a measure of quantitative stability, that is, the stability of any type of genotype is only based on the distance from the genotype point to the central point in the AMMI graph Purchase et al. [20] developed the AMMI stability value (ASV) based on the AMMI model's IPCA1 and IPCA2 (interaction principal components analysis 1 and 2, respectively) scores for each genotype. Purchase et al. [20] noted that ASV was equivalent to the stability method of Eberhart and Russel [21] and Shukla [22]. Clone 1 (PC1), 4 (PC4), 6 (PC6), 8(UJ3) and clone 9 (UJ5) had lower ASV compared to the average of ASV (Table 4). Clone 1 (PC1), 4 (PC4), 6 (PC6), 8 (UJ3) and clone 9 (UJ5) have lower ASV compared to the average ASV (Table 4). This means that these clones were more stable than the PC2, PC3, PC5 and PC7 clones. These results were comparable to those of IPCA1 and IPC2 graph (Figure 2).

Table 2. Combination analysis of variance of 9 cassava clones and 8 starch production environments.

\begin{tabular}{|l|c|c|}
\hline \multicolumn{1}{|c|}{ Source } & $\begin{array}{c}\text { Degree of } \\
\text { Freedom }\end{array}$ & Mean Square \\
\hline Environment [E] & 7 & $50.50^{* *}$ \\
\hline Error (a) & 16 & 2.37 \\
\hline Clone [C] & 8 & $16.82^{* *}$ \\
\hline C x E & 56 & $1.90^{* *}$ \\
\hline Error (b) & 128 & 0.78 \\
\hline Coefficient Variation. (\%) & 15 \\
\hline$* *=1 \%$ significantly different & \\
\hline
\end{tabular}

Table 3. Principal components analysis

\begin{tabular}{|l|l|l|l|l|l|l|}
\hline Component & IPCA1 & IPCA2 & IPCA3 & IPCA4 & IPCA5 & IPCA6 \\
\hline percent & 42.7 & 27.1 & 16.2 & 7.5 & 6.0 & 0.5 \\
\hline Accumulation (\%) & 42.7 & 69.8 & 86 & 94 & 99.5 & 100 \\
\hline DF & 14 & 12 & 10 & 8 & 6 & 4 \\
\hline SS & 45.47 & 28.87 & 17.23 & 7.97 & 6.35 & 0.53 \\
\hline MS & 3.25 & 2.41 & 1.72 & 0.10 & 1.06 & 0.13 \\
\hline Prob. F & 0.00 & 0.00 & 0.02 & 0.25 & 0.23 & 0.95 \\
\hline
\end{tabular}


Table 4. IPCA value of clone and starch production in six months.

\begin{tabular}{|l|l|c|r|r|r|r|}
\hline No. & Clone & $\begin{array}{c}\text { Starch } \\
\text { production } \\
(\mathbf{t} / \mathbf{h a})\end{array}$ & IPCA1 & \multicolumn{1}{c|}{ IPCA2 } & \multicolumn{1}{c|}{ IPCA3 } & \multicolumn{1}{c|}{ ASV } \\
\hline 1 & PC1 & 6.31 & 0.329 & 0.040 & -0.064 & 0.578 \\
\hline 2 & PC2 & 5.78 & 0.766 & 0.257 & -0.082 & 1.249 \\
\hline 3 & PC3 & 4.81 & 0.584 & -0.614 & -0.316 & 1.210 \\
\hline 4 & PC4 & 7.21 & 0.557 & 0.087 & -0.835 & 0.993 \\
\hline 5 & PC5 & 5.80 & -1.480 & 0.465 & 0.771 & 2.386 \\
\hline 6 & PC6 & 6.77 & 0.093 & 0.786 & -0.425 & 0.152 \\
\hline 7 & PC7 & 4.76 & -0.068 & -1.206 & -0.029 & 1.211 \\
\hline 8 & UJ3 (check) & 5.21 & -0.529 & -0.322 & 0.897 & 0.838 \\
\hline 9 & UJ5 (check) & 5.87 & -0.253 & 0.507 & 0.082 & 0.732 \\
\hline
\end{tabular}

The correlation between IPCA value and soil properties based on 7-month starch yield is shown in Table 5. This correlation is useful for the biological explanation of interaction effects. The IPCA1 component was positively correlated with the content of N. IPCA1 If the nitrogen content in the soil increases, it will increase. The nitrogen content in the soil was an important factor in determining the stability of the clone, although all nitrogen content in the environment was classified as low level according to the standards reported by Howeler [23]. The $\mathrm{N}$ content of the environments used ranged from $0.06 \%-0.13 \%$. However, Sholihin $[24,25,26]$ reported that a $0.060-14 \%$ change in $\mathrm{N}$ content in soil did not affect the stability of clones related to starch yield at 6 and 9 months and fresh tuber yield at 9 months, the location number in this study were 4 locations.

IPCA1 was also positively correlated with CEC of soil, IPCA1 will increase if CEC of soil increase. It means CEC of soil was important factor in determining the stability of clone. The range of CEC of soil of the environments used was $2.85-16.3 \mathrm{me} / 100 \mathrm{~g}$. According to the Landon report standards, these are classified as low and intermediate. [28]. However, Sholihin [24-26] reported that CEC of soil ranged in 6.82-23.9 me/100 $\mathrm{g}$ did not affect the stability of clones related to starch yield in 6 and 9 months and fresh tuber yield in 9 months. IPCA1 was negatively correlated with $\mathrm{P}_{2} \mathrm{O}_{5}$ content, it means $\mathrm{P}_{2} \mathrm{O}_{5}$ content of soil was also important factor in determining the stability of clone in related to starch yield in seven months. The P2O5 content of the medium used by ranges from $1.36 \mathrm{ppm}$ to $29.9 \mathrm{ppm}$. According to the standards reported by Howeler [27], these are classified as very low to moderate levels. Sholihin [18] reported that $\mathrm{P}_{2} \mathrm{O}_{5}$ content of soil ranged in 1.27-105 ppm was positively correlated to IPCA2 which was related to starch yield in 9 months. However, Sholihin $[25,26]$ reported that the change of $\mathrm{P}_{2} \mathrm{O}_{5}$ content in the environment of $1.27105 \mathrm{ppm}$ does not affect the clonal stability related to the 6-month starch yield and the 9-month fresh tuber yield.

The correlation between the IPCA value and rainfall is given in Table 6. There was no correlation between IPCA values and number of rainy days/month and a total rainfall/month during growing periods. This was assumed because of there was rainfall during growing periods at least 6 days during each month in all environments. Besides that, the climate of all environment used were classified as humid area. Sholihin [25] reported that there was no correlation between number of rain/month and rainfall/months with IPCA values related to starch yield in six months. However, Sholihin [24] reported that number of rainy days/month and total rainfall/month in 5 months after planting were correlated with IPCA2 values in related to the starch yield in nine months, the climate of environments used at that time were classified as humid and dry area. 
Table 5. Correlation between the IPCA value and soil characteristics of the soil.

\begin{tabular}{|l|c|c|c|}
\hline Soil characteristics & IPCA1 & IPCA2 & IPCA3 \\
\hline Cation exchange capacity & $0.741^{*}$ & -0.542 & -0.042 \\
\hline Content of C-organic & -0.075 & -0.416 & 0.148 \\
\hline Content of $\mathrm{Fe}$ & 0.333 & 0.613 & -0.174 \\
\hline $\mathrm{S}$ oil $\mathrm{pH}$ & 0.160 & -0.655 & -0.265 \\
\hline $\mathrm{AL}-\mathrm{dd}$ & 0.079 & 0.383 & 0.151 \\
\hline Sea level & 0.532 & -0.400 & 0.286 \\
\hline $\mathrm{N}$ content & $0.798^{* *}$ & 0.423 & 0.414 \\
\hline Content of $\mathrm{P}_{2} \mathrm{O}_{5}$ & $-0.761^{*}$ & -0.370 & 0.341 \\
\hline Content of potassium & -0.258 & -0.256 & -0.099 \\
\hline$*=$ probability $=0.05 ; * *$ probability $=0.01$ & \\
\hline
\end{tabular}

Table 6. Correlation between the IPCA value and the rainfall.

\begin{tabular}{|l|c|c|c|}
\hline \multicolumn{1}{|c|}{ Rainlfall } & IPCA1 & IPCA2 & IPCA3 \\
\hline Rainy days at first month & -0.504 & 0.119 & 0.107 \\
\hline Rainy days at second month & 0.541 & -0.353 & -0.088 \\
\hline Rainy days at third month & -0.226 & 0.242 & 0.224 \\
\hline Rainy days at fourth months & -0.259 & 0.485 & -0.241 \\
\hline Rainy days at fifth months & -0.282 & -0.165 & 0.564 \\
\hline Rainy days at sixth months & 0.189 & -0.073 & -0.243 \\
\hline Rainy days at seventh months & -0.388 & 0.450 & -0.376 \\
\hline Rainfall at first month & -0.479 & 0.265 & 0.507 \\
\hline Rainfall at second month & 0.176 & 0.391 & -0.306 \\
\hline Rainfall at third month & -0.250 & 0.654 & -0.404 \\
\hline Rainfall at fourth months & -0.292 & 0.250 & 0.219 \\
\hline Rainfall at fifth months & -0.433 & -0.319 & -0.272 \\
\hline Rainfall at sixth months & 0.242 & 0.387 & 0.262 \\
\hline Rainfall at seventh months & -0.551 & 0.136 & 0.579 \\
\hline
\end{tabular}

Table 7 shows the IPCA values and average starch yields of the eight environments. Tulang Bawang Barat had a value of IPCA1 of -0.972 . IPCA1 was positively correlated with $\mathrm{N}$ content and cation exchange capacity (CEC) of soil on topsoil. It means that Tulang Bawang Barat had relatively low $\mathrm{N}$ content and CEC of soil. Based on the soil analysis, $\mathrm{N}$ content and CEC of soil in Tulang Bawang Barat were $0.06 \%$ for $\mathrm{N}$ content and 3.13 $\mathrm{Cmol}+/ \mathrm{kg}$ for CEC. That was different from that in Lampung Selatan 2016, IPCA1 value of Lampung Selatan 2016 was 1.096, and it means that Lampung Selatan 2016 had high N content and CEC of soil. Based on the soil analysis, Lampung Selatan 2016 had N content of $0.13 \%$ and soil CEC of $16.3 \mathrm{Cmol}+/ \mathrm{kg}$. IPCA1 was negatively correlated with $\mathrm{P}_{2} \mathrm{O}_{5}$ content of topsoil. IPCA1 value of Tulang Bawang Barat was -0.972 , indicates that the P2O5 content in the soil of Tulang Bawang Barat was high. According to soil analysis, the P2O5 content of Tulang Bawang Barat soil was 29.9 ppm. That was different to Lampung Selatan 2016. IPCA1 value in Lampung Selatan 2016 was 1.096, which means that Lampung Selatan 2016 had relatively low $\mathrm{P}_{2} \mathrm{O}_{5}$ content. Based on the soil analysis, $\mathrm{P}_{2} \mathrm{O}_{5}$ content in Lampung Selatan 2016 was 4.35 ppm. 
Table 7. IPCA1 Environmental value and average starch yield.

\begin{tabular}{|l|c|c|}
\hline \multicolumn{1}{|c|}{ Environments } & $\begin{array}{c}\text { Starch production } \\
\text { (ton/hectare) }\end{array}$ & IPCA1 \\
\hline Lampung Selatan 2015 & 8.516 & -0.319 \\
\hline Lampung Timur 2015 & 6.715 & -0.131 \\
\hline Lampung Selatan 2016 & 6.099 & 1.096 \\
\hline LampungTimur2016 & 5.612 & -0.968 \\
\hline Lampung Tengah 2016 & 3.830 & 0.175 \\
\hline Lampung Selatan 2017 & 5.102 & 0.690 \\
\hline Lampung Timur 2017 & 5.614 & 0.430 \\
\hline Tulang Bawang Barat 2018 & 5.198 & -0.972 \\
\hline
\end{tabular}

IPCA values for nine clones is presented in Table 4. Clone PC4 have high IPCA1 (0.557) indicating their adaptation to high $\mathrm{N}$ content and CEC on topsoil, because IPCA1 values were positively correlated with $\mathrm{N}$ content on topsoil. Clone PC4 has a high IPCA1 (0.557), which indicates that PC4 was adapted to the high content of N and CEC in the upper soil layer, because the value of IPCA1 was positively correlated with the $\mathrm{N}$ content in the layer. surface of the soil. Clone PC4 was also adapted to low $\mathrm{P}_{2} \mathrm{O}_{5}$ content in the upper soil layer because IPCA1 is negatively correlated with $\mathrm{P}_{2} \mathrm{O}_{5}$ content.

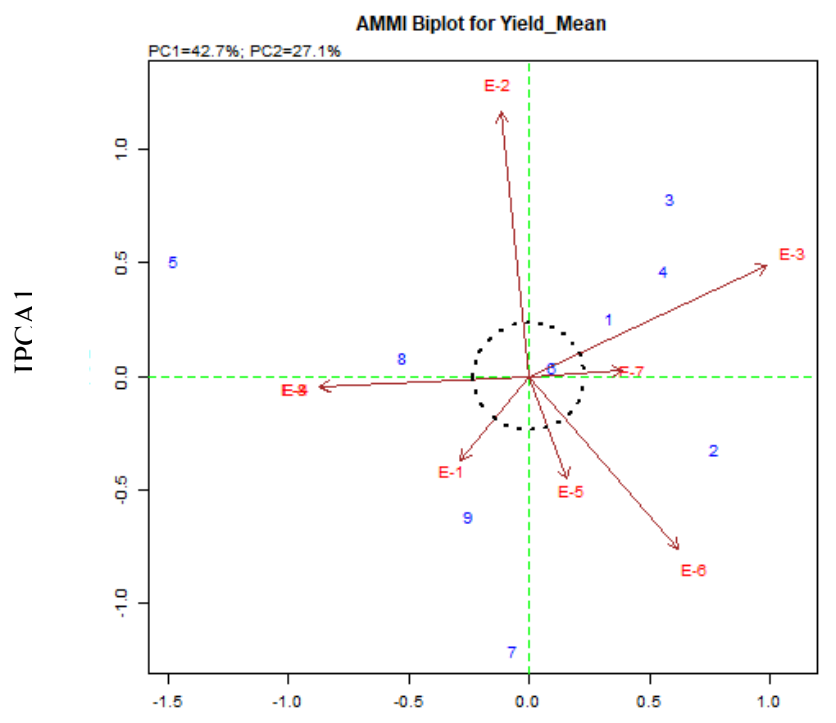

IPCA2

Fig. 2. Graph of IPCA1 and IPCA2 based on clones of starch production in seven months.

Note: 1: PC1; 2: PC2; 3 : PC3; 4: PC4; 5: PC5; 6: PC6; 7: PC7; 8 UJ3; 9: UJ5

E-1 : Lampung Selatan 2015 E-2: Lampung Timur 2015

E-4 : LampungTimur2016 E-5: Lampung Tengah 2016

E-7 : Lampung Timur 2017 E-8: Tulang Bawang Barat 2018
E-3: Lampung Selatan 2016

E-6: Lampung Selatan 2017 


\section{Conclusion}

Clone PC4 produced starch yield the highest, significantly higher than UJ3 and UJ5. That clone is potential to be developed in the acid area in Lampung. Clone PC4 was more stable than the existing varieties (UJ3 and UJ5). Based on the 7-month starch yield, the environmental factors that affect the stability of cassava clones were the $\mathrm{N}$ and P2O5 content of the upper soil layer and the CEC of the soil.

\section{References}

1. Anonymous. HS Icon Manioc (Cassava) Starch. At https://oec.world/en/profile/hs92/manioc-cassava-starch

2. TTDI. Weekly tapioca starch price. At http://www.thaitapiocastarch.org/en/information/statistics

3. Anonymous. Fortune business insight. At https://www.fortunebusinessinsights.com/cassava-starch-market-102415

4. T. Sundari, K. Noerwijati, I.M.J. Mejaya, J. Penelitian Pertanian Tanaman Pangan 29, (2010)

5. K. Kawano, K. Narintaraporn, P. Narintaraporn, S. Sarakarn, A. Limsila, J. Limsila, D. Suparhan, V. Sarawat, W. Watananonta. Crop Sci 38. (1998)

6. R.H. Howeler, Agronomy research in the Asia cassava network - an overview 19871990, in Cassava breeding, agronomy and utilization research in Asia, Proc. $3^{\text {rd }}$ regional workshop held in Malang, Indonesia, Oct 22-27 1990, Thailand (1992)

7. R.H. Howeler,_Result of soil analyses in Asia 1995-2000, in Cassava's potential in Asia in the $21^{\text {st }}$ Century: present situation and future research and development needs, Proceeding of the sixth regional workshop held in Ho Chi Minh City, Vietnam, Feb 2125, 2000, Thailand (2001)

8. K. Agahi, J. Ahmadi, H.A. Oghan, Fotokian, S.F. Orang. Crop Breeding and Applied Biotechnology 20 (2020)

9. C. Singh, A. Gupta, V. Gupta, P. Kumar, R. Sendhil, B.S. Tyagi, G. Singh, R. Chatrath, G.P. Singh. Crop Breeding and Applied Biotechnology 19. (2019)

10. L.K. de Morais, A.D. Santiago, M.H.B. Crop Breeding and Applied Biotechnology 19, (2017)

11. T. Sitaresmi, W.B. Suwarno, C. Gunarsih, Y. Nugraha, P. Sasmita, A.A. Daradjat. J. of Breed. Genet. 51. (2019)

12. N. Kartina, B.S. Purwoko, I.S. Dewi, D. Wirnas, Sugiyanta. J. of Breed. Genet. 51. (2019)

13. Krisdiana, Penyebaran varietas unggul dan preferensi petani terhadap komoditas ubikayu (Unpublished)

14. Anonyous. BPS. https://www.bps.go.id/indicator/53/21/1/luas-panen.html

15. N. Dhuria, A. Babbar. Legume Research 44, 31-35 (2021)

16. C. Shobanadevi, R. Elangaimanna, K. Vadivel. Indian J. of Agric. Res. 10. (2021)

17. J. Bocianowski, A. Tratwal, K. Nowosad. Euphytica 217, 26 (2021)

18. J.R. Lamichhane, J.N. Aubertot, L. Champolivier, Debaeke,P. Maury.. Frontiers in Plant Science 11, (2020)

19. M. Sara, R. Abbas, A. Reza, E. Alireza. Indian J. Genet. 79, (2019)

20. J.L. Purchase, H. Hatting, C.S. Van Deventer. South Africa Journal of Plant and Soil 17, (2000)

21. S.A. Ebberhart, W.L. Russel. Crop Sci. 6 (1966)

22. G.K. Shukla. Heredity 29. (1972) 
23. R.H. Howeler. Mineral Nutrition and Fertilization of Cassava (Manihot esculenta Crantz), (CIAT, Colombia, 1981)

24. Sholihin. Indonesian Journal Agricultural Science 10. (2009)

25. Sholihin. HAYATI Journal of Bioscience 18, 21-26 (2011)

26. Sholihin, Analisis interaksi genotipe x lingkungan untuk hasil ubi segar dengan model AMMI. Prosiding Seminar Nasional, Pemuliaan Berbasis Potensi dan Kearifan Lokal Menghadapi Tantangan Global 2011.

27. J.R. Landon. Booker Tropical Soil Manual, (Pitman Press Limited, Great Britain, 1984) 